\title{
Numerical Study of Mixed Convection in a Photovoltaic Trombe Wall Channel Coupled with a Solar Chimney Integrated into a Building for Habitats Passive Cooling
}

\author{
Yawovi Nougbléga ${ }^{*}$, Koffi Sagna ${ }^{2}$, Hodo-Abalo Samah ${ }^{3}, K_{\text {Kodjo Kpode }}^{3}$ \\ ${ }^{1}$ Laboratoire Sur l'Energie Solaire /Groupe Phénomène de Transfert et Energétique, Université de Lomé, Lomé, Togo \\ ${ }^{2}$ Laboratoire Sur l'Energie Solaire/Chaire UNESCO sur les Energies Renouvelables, Université de Lomé, Lomé, Togo \\ ${ }^{3}$ Département de Physique, Université de Kara, Kara, Togo \\ Email: *nycogl@yahoo.fr
}

How to cite this paper: Nougbléga, Y., Sagna, K., Samah, H.-A. and Kpode, K. (2020) Numerical Study of Mixed Convection in a Photovoltaic Trombe Wall Channel Coupled with a Solar Chimney Integrated into a Building for Habitats Passive Cooling. Open Journal of Applied Sciences, 10, 844-863.

https://doi.org/10.4236/ojapps.2020.1012060

Received: November 4, 2020

Accepted: December 27, 2020

Published: December 30, 2020

Copyright $\odot 2020$ by author(s) and Scientific Research Publishing Inc. This work is licensed under the Creative Commons Attribution International License (CC BY 4.0).

http://creativecommons.org/licenses/by/4.0/

(c) (i) Open Access

\begin{abstract}
The solar chimney can generate airflow through the living space of the building to provide cooling. Hence, solar energy represents the best renewable, environmentally friendly source of energy that can be used for heating and cooling of houses. The present paper reports the numerical study of the performance of the mixed convection in the associated hybrid Photovoltaic/Thermal chimneys integrated into building for natural habitat ventilation. The front side glass plate of the chimneys is heated by a non-uniform daily solar radiation flux. Air is considered to be the cooling fluid. The stream fucntion-vorticity formulation with a finite difference numerical discretization solution scheme has been adopted. The system of algebraic governing equations is solved by Thomas algorithm method. The aim of the present paper is to study and to predict the dynamic fields and particularly of the mass flow rate of the air thermosiphon drawing in the associated hybrid Photovoltaic-Thermal chimneys integrated into a building for passive cooling in the habitats. The effects of the governing parameters, namely Reynolds number $(30 \leq \mathrm{Re} \leq 200)$, Rayleigh number $(103 \leq \mathrm{Ra} \leq 105)$, the integrated chimney width on the fluid flow and the heat transfer characteristics, are studied in detail. The local Nusselt number, streamlines, isotherms, PV cells electrical efficiency and the outlet velocity at the top of the channels are the results represented versus the above controlling parameters.
\end{abstract}

\section{Keywords}

Trombe Wall, Passive Cooling, Associated Chimneys, Electrical Efficiency, Thermal Comfort 


\section{Introduction}

Energy use in buildings has a large part of global and regional energy demand. The share of heating and cooling in total building energy demand is very diverse varying between $18 \%$ and $73 \%$ worldwide [1]. In Parallel to the global population growth, energy consumption and environmental issues are today an increasing and global concern. According to the World Energy Council, primary energy demand will double by 2050 [2]. The building sector is responsible for nearly $40 \%$ of national energy consumption and $25 \%$ of greenhouse gas emissions in developed countries [3]. A few decades ago, researchers were concerned about innovative strategies reducing energy consumption in building design. For instance, bioclimatic design involves the application of energy conservation techniques in building construction with the scope of renewable energy sources such as solar energy [4]. One challenging aspect is satisfying the thermal comfort based on bioclimatic design. It can contribute significantly to the climate change and has a considerable overall environmental impact. For these reasons, the buildings we find today are expected to achieve both energy efficient and environmental-friendly design, using renewable energy partly or completely instead of fossil energy for heating and cooling, particularly solar energy that utilizes cost-free solar radiation from the sun. In this perspective, the integration of passive solar systems in buildings is one strategy for sustainable development and increasingly encouraged by international regulations. Passive solar techniques can reduce annual heating demand up to 25\% [5]. Various architectural devices, such as solar chimneys [6], solar roofs [7], Trombe walls, etc., are used in construction. Among these devices, Trombe walls [8] [9], which are known as storage walls and solar heating walls [9] [10], can harmonize the relationship between humans and the natural environment and are widely used because of advantages such as simple configuration, high efficiency, zero running cost and so on. In addition to being environmentally friendly, using a Trombe wall in building can reduce a building's energy consumption up to 30\% [11]. A similar result was presented by Briga-Sá et al. [8]. Energy heating savings of 16.36\% were achieved if a Trombe wall was added to the building envelope. The integration of renewable energy systems will be one of the solutions to the key issues of economizing fossil resources, of which world reserves are limited, and reducing the effects of global warming. Solar energy represents the best renewable, environmentally friendly source of energy that can be used for the heating and cooling of houses. In the recent ingenious practices, the ventilation could be dominated by the thermal buoyancy, because the outdoor air will enter the building via the ventilation openings of the rooms and will exit though a Hybrid Photovoltaic-Thermal chimney to evacuate hot and polluted air. This Hybrid Photovoltaic-Thermal (PV/T) is a combination of photovoltaic and solar thermal component integrated into one system capable of producing both electrical and thermal energy simultaneously [12]. The effect of the air flow induced by free convection behind the photovoltaic panels has been studied by Brinkworth et al. 
[13]; they found that the air flow induced by buoyancy forces can reduce the module's temperature by $20 \mathrm{~K}$. By employing passive cooling techniques into contemporary buildings, architects can eliminate mechanical cooling or even to a small extent decrease the size and cost of the equipment [14]. Barozzi et al. [15] studied space conditioning in buildings is a function of temperature, relative humidity, irradiation and the method of controlling these parameters. The space conditioning is highly desirable in tropical countries, like India, Africa and South America. Today's technology like passive solar applications can be used for thermal comfort of buildings [16]. The ventilation provided by the solar chimney is not sufficient for large length and width buildings, but solar chimney enhances the ventilation rate up to some extent. One important application of passive cooling for air ventilation and circulation in the form of wind tower was suggested by Bansal et al. [17]. Hence, Qirong et al. [18] proposed an integrated approach of Trombe wall, roof solar collector and chimney and investigated the effect of total length and width of chimney on the performance of the system. They reported that the performance of integrated system found better as compared to the single solar chimney. Many researchers are agreed that global warming may be one of the greatest threats facing the planet. This led to the new requirements for developing ingenious natural ventilation systems. The ambient air temperature can circulate in the building with the aid of a solar chimney. However, stand-alone solar chimney is incapable of satisfying thermal comfort in extreme hot weather. Precooling the outdoor air with a cooling cavity is regarded as one of the most effective methods to keep the room temperature low. In order to overcome the inadequacy of a Trombe wall application for natural cooling, Rabani et al. [19] proposed a coupled solar chimney-Trombe wall accompanied by a water spraying system increasing the air humidity for a hot dry climate in Yazd, Iran. Hence, Bansal et al. [20] signified that evaporative cooling could maintain the room temperature at a desired level. Mathews et al. [21] simulated the integration of an evaporative cooling system with a building by a computer program. The program assured the thermal comfort for more than $80 \%$ of well designed buildings in South Africa. Sumathy et al. [22] presented a parametric analytical study on the enhancement of natural ventilation in a solar house induced by a solar chimney and an adsorption cavity for a humid climate. A comparison between the ventilation effect of the solar chimney and the combined system was also provided without considering the wind effect. The literature survey indicates that a considerable body of literature on solar chimney exists. In recent years there has been a growing interest in introducing innovative strategies taking advantage of solar chimney integrated systems. A few papers have addressed the integrated systems for space heating/cooling, [23] [24] [25] [26]. But, accordingly, the aim of this manuscript is a contribution to recent progresses in solar photovoltaic chimney Trombe wall coupled with the air cooling cavity integrated into a building for habitats passive cooling. A literature review of the subject shows that many authors have studied mixed convection in 
solar chimneys, [22]-[29]. A part from studies on Trombe wall that sometime take into account the air flow inside buildings; most of the studies are related to solar chimneys coupled to the cooling cavity [30] [31] [32]. There is no work according to the solar photovoltaic Trombe wall chimney coupled with the cooling cavity integrated into a building in the literature. From where, the present study that the solar Trombe wall chimney coupled with a hybrid photovoltaic-thermal chimney integrated into a building, where the chimneys plates are subjected to the heat flux of the solar radiation and consequently the thermal and dynamic fields evolve in the time and the space until to attain the steady state. Hence, the aim of the present paper is to study numerically a mixed convection problem in a photovoltaic Trombe wall coupled with a heated hybrid Photovoltaic-Thermal chimney integrated into a building for enhancing the natural ventilation to keep the thermal comfort in the large length and width buildings. In this analysis, the fresh ambient forced air flow enters the large length and width building through an inlet opening located near the lower part of the left insulated vertical adiabatic wall and exits from the photovoltaic Trombe wall chimney and the solar chimney integrated into the building. The ventilation supports a double interaction between the buoyancy induced flow and the forced flow. In the lower part of the room, the fresh forced flow injected into the room promotes the natural convection motion. A computational fluid dynamics (CFD) technique was combined with the thermal model to evaluate the predicted air movement in the room and in the chimneys. A numerical simulation has been conducted to determine heat transfer, flow rate, solar cells PV efficiency and the effect of geometrical parameters of the room and the associated integrated chimneys.

\section{Mathematical Formulation}

\subsection{Physical Model and Governing Equations}

The physical model deals with a simple habitat with length $\mathrm{L}$ and height $\mathrm{h} 1$ where a solar chimney is integrated into the right side of the roof top whereas the photovoltaic Trombe wall chimney integrated to the south façade of the building.

The associated chimneys are designed as a solar collector with plate separation $\mathrm{d}$ and height $\mathrm{h} 2$. The principal components elements of the solar chimneys are the front glass cover, the silcon polycristallin semi-transparent photovoltaic cells (PV), air flow, absorber plate and back adiabatic panel. The associated chimneys act as the exhaust fan by sucking the room air and venting it out during sunshine hours. In the system, the solar PV panels absorbed the incident solar radiation and transfer heat to the air in the gaps by convection and radiation phenomena. The back walls temperature rise and in turn, together with the solar PV cells, heat the air in the gaps. The right side wall is maintained at the ambient temperature whereas the upper wall and the floor of the room are assumed to be perfectly insulated and adiabatic. The physical system is sketched in Figure 1. 


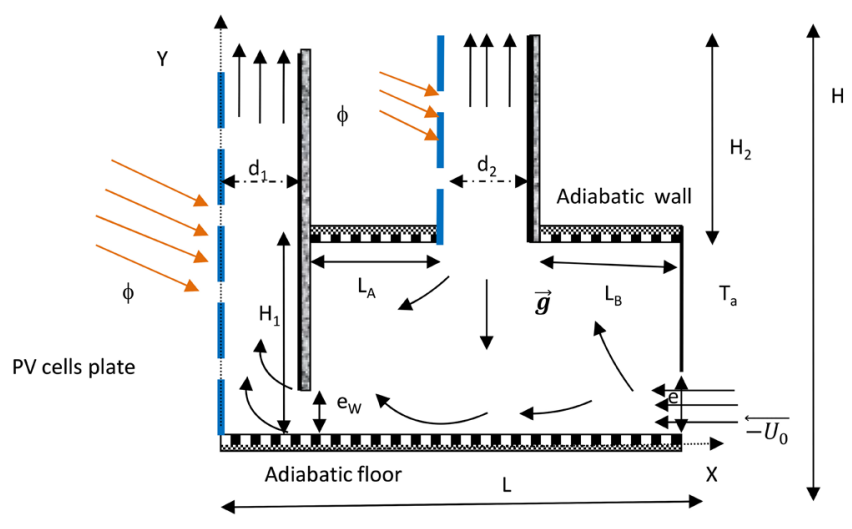

Figure 1. Physical model.

The non dimensional set of the governing equations (continuity, momentum and energy equations) for a two-dimensional, incompressible laminar flow are the following:

$$
\begin{gathered}
\partial U / \partial X+\partial V / \partial Y=0 \\
\partial \omega / \partial \tau+U \partial \omega / \partial X+V \partial \omega / \partial Y=\operatorname{Ri} \partial \theta / \partial X+1 / \operatorname{Re}\left(\partial^{2} \omega / \partial X^{2}+\partial^{2} \omega / \partial Y^{2}\right) \\
\partial \theta / \partial \tau+U \partial \theta / \partial X+V \partial \theta / \partial Y=1 / \operatorname{Re} \operatorname{Pr}\left(\partial^{2} \theta / \partial X^{2}+\partial^{2} \theta / \partial Y^{2}\right) \\
\omega=-\left(\partial^{2} \psi / \partial X^{2}+\partial^{2} \psi / \partial Y^{2}\right)
\end{gathered}
$$

The stream function and the vorticity are related to the velocity components by the following expressions:

$$
U=\partial \psi / \partial Y ; V=-\partial \psi / \partial X \text { and } \omega=(\partial V / \partial X-\partial U / \partial Y)
$$

Where the scales are defined: $X=x / d ; Y=y / d ; U=u / u_{0} ; V=v / u_{0}$

$$
\begin{aligned}
& \Psi=\psi /\left(u_{0} d\right) ; \omega=\Omega d / u_{0} ; \theta=\lambda\left(T-T_{a}\right) / \phi d ; \\
& \operatorname{Re}=\left(\rho v_{0} d\right) / \mu ; G r=\left(g \beta \phi d^{4}\right) /\left(\lambda V^{2}\right)
\end{aligned}
$$

\subsection{Initial and Boundary Conditions}

By introducing the non dimensional parameters into the physical boundary conditions illustrated in Figure 1, the following non dimensional boundary conditions are obtained:

$$
\begin{gathered}
\theta=0 ; U=V=\omega=\psi=0 \text { at } \tau=0 \\
\text { at } \tau>0
\end{gathered}
$$

The boundary conditions, associated with the problem are as follows:

$$
\begin{gathered}
X=L^{*} \text { and } 0 \leq Y \leq e^{*}: \theta=0 ; V=0 ; U=-1 ; \omega=0 ; \psi=-Y \\
X=L^{*} \text { and } e^{*} \leq Y \leq H_{1}^{*}: \theta=0 ; V=0 ; U=0 ; \omega=-\left.\frac{\partial^{2} \psi}{\partial X^{2}}\right|_{X=L^{*}} ; \psi=0 \\
Y=0 \text { and } 0 \leq X \leq L^{*}: U=V=\psi=0 ;\left.\frac{\partial \theta}{\partial Y}\right|_{Y=0}=0 ; \omega=-\left.\frac{\partial^{2} \psi}{\partial Y^{2}}\right|_{Y=0}
\end{gathered}
$$




$$
\begin{aligned}
& Y=H_{1}^{*} \text { and } d_{1}^{*} \leq X \leq L_{A}^{*}: U=V=\psi=0 ;\left.\frac{\partial \theta}{\partial Y}\right|_{Y=H_{1}^{*}}=0 ; \omega=-\left.\frac{\partial^{2} \psi}{\partial Y^{2}}\right|_{Y=H_{1}^{*}} \\
& Y=H_{1}^{*} \text { and } d_{2}^{*} \leq X \leq L^{*}: U=V=\psi=0 ;\left.\frac{\partial \theta}{\partial Y}\right|_{Y=H_{1}^{*}}=0 ; \omega=-\left.\frac{\partial^{2} \psi}{\partial Y^{2}}\right|_{Y=H_{1}^{*}} \\
& X=L_{A}^{*} \text { and } H_{1}^{*} \leq Y \leq H^{*}: U=V=\psi=0 ; \omega=-\left.\frac{\partial^{2} \psi}{\partial X^{2}}\right|_{X=L_{A}^{*}} \\
& X=L_{A}^{*} \text { and } H_{1}^{*} \leq Y \leq H^{*}:\left.\frac{\partial \theta}{\partial X}\right|_{X=L_{A}^{*}}=\left(\eta_{e l}-\tau_{g l} \alpha_{P V}\right)-\left(\frac{q_{r_{P V, a b s}}}{\phi}\right) \\
& X=d_{2}^{*} \text { and } H_{1}^{*} \leq Y \leq H^{*}: U=V=\psi=0 ; \omega=-\left.\frac{\partial^{2} \psi}{\partial X^{2}}\right|_{X=d_{2}^{*}} \\
& X=d_{2}^{*} \text { and } H_{1}^{*} \leq Y \leq H^{*}:-\left.\frac{\partial \theta}{\partial X}\right|_{X=d_{2}^{*}}=\left(\tau_{g l} \alpha_{P V} \alpha_{a b s}\right)-\left(\frac{q_{r_{a b s, P V}}}{\phi}\right) \\
& Y=H^{*} \text { and } L_{A}^{*} \leq X \leq L_{B}^{*}:\left.\frac{\partial U}{\partial Y}\right|_{Y=H^{*}}=\left.\frac{\partial V}{\partial Y}\right|_{Y=H^{*}}=\left.\frac{\partial \psi}{\partial Y}\right|_{Y=H^{*}}=\left.\left.\frac{\partial \omega}{\partial Y}\right|_{Y=H^{*}} \frac{\partial \theta}{\partial Y}\right|_{Y=H^{*}}=0 \\
& X=0 \text { and } 0 \leq Y \leq H^{*}: U=V=\psi=0 ; \omega=-\left.\frac{\partial^{2}}{\partial X^{2}}\right|_{X=0} ; \\
& \left.\frac{\partial \theta}{\partial X}\right|_{X=0}=\left(\eta_{e l}-\tau_{g l} \alpha_{P V}\right)-\left(\frac{q_{r_{P V, a b s}}}{\phi}\right) \\
& X=d_{1}^{*} \text { and } e_{w}^{*} \leq Y \leq H^{*}: U=V=0 ; \psi=0 ; \omega=-\left.\frac{\partial^{2} \psi}{\partial X^{2}}\right|_{X=d_{1}^{*}} \\
& X=d_{1}^{*} \text { and } e_{w}^{*} \leq Y \leq H^{*}:-\left.\frac{\partial \theta}{\partial X}\right|_{X=d_{1}^{*}}=\left(\tau_{g l} \alpha_{P V} \alpha_{a b s}\right)-\left(\frac{q_{r_{a b s, P V}}}{\phi}\right)
\end{aligned}
$$

At the outlet of the chimneys:

If $V\left(X, H^{*}\right) \geq 0$ and $\boldsymbol{V}\left(X, H^{*}\right) \cdot \boldsymbol{n}>0$

$$
\begin{aligned}
& Y=H^{*} \text { and } 0 \leq X \leq d_{1}^{*} \text { or } L_{A}^{*} \leq X \leq d_{2}^{*}: U=0 \\
& \left.\frac{\partial V}{\partial Y}\right|_{Y=H^{*}}=\left.\frac{\partial \theta}{\partial Y}\right|_{Y=H^{*}}=\left.\frac{\partial \omega}{\partial Y}\right|_{Y=H^{*}}=\left.\frac{\partial \psi}{\partial Y}\right|_{Y=H^{*}}=0
\end{aligned}
$$

If $V\left(X, H^{*}\right) \leq 0$ and $\boldsymbol{V}\left(X, H^{*}\right) \cdot \boldsymbol{n}<0$

$$
\begin{gathered}
Y=H^{*} \text { and } 0 \leq X \leq d_{1}^{*} \text { or } L_{A}^{*} \leq X \leq d_{2}^{*}: U=\theta=0 \\
\left.\frac{\partial V}{\partial Y}\right|_{Y=H^{*}}=\left.\frac{\partial \omega}{\partial Y}\right|_{Y=H^{*}}=\left.\frac{\partial \psi}{\partial Y}\right|_{Y=H^{*}}=0 \\
q_{r_{a b s, P V}}=\sigma \frac{\left(T_{P V}^{4}-T_{a b s}^{4}\right)}{\left(\frac{1}{\varepsilon_{P V}}+\frac{1}{\varepsilon_{a b s}}-1\right)} ; q_{r_{P V, a b s}}=\sigma \frac{\left(T_{a b s}^{4}-T_{P V}^{4}\right)}{\left(\frac{1}{\varepsilon_{P V}}+\frac{1}{\varepsilon_{a b s}}-1\right)}
\end{gathered}
$$

Heat Transfer 
The most important heat transfer is evaluated through the PV cells modules plates along the chimneys. These are best represented by Nusselt number. The local Nusselt number along the solar PV cells panels of the chimneys are given by:

$$
\begin{gathered}
X=0 \text { and } 0 \leq Y \leq H^{*}: N u_{P V}(Y)=\frac{\phi d}{\lambda\left(T_{P V}(0, Y)-T_{a}\right)}=\frac{1}{\theta_{P V 1}(0, Y)} \\
X=L_{A}^{*} \text { and } H_{1}^{*} \leq Y \leq H^{*}: N u_{a b s}(Y)=\frac{\phi d}{\lambda\left(T_{P V}\left(L_{A}^{*}, Y\right)-T_{a}\right)}=\frac{1}{\theta_{P V 2}\left(L_{A}^{*}, Y\right)}
\end{gathered}
$$

The electrical efficiency of the solar PV cells is given as follows:

$$
\begin{gathered}
\eta_{e l}=\eta_{r e f}+\beta_{p v}\left(\overline{T_{P V}}-298\right)+\gamma \log \left(\frac{\phi}{1000}\right) \\
\overline{T_{P V}}=\frac{1}{H} \int_{0}^{H} T_{P V}(0, y) \mathrm{d} y
\end{gathered}
$$

where $\overline{T_{P V}}$ is the average absolute temperature of the PV plate

\subsection{Numerical Procedure}

The non linear partial differential governing Equations, (1-3), were discretized using a finite difference technique. The first and second derivatives of the diffusive terms were approached by central differences while a second order upwind scheme was used for the convective terms to avoid possible instabilities frequently encountered in mixed convection problems. The integration of Equations (2-3) was assured by Thomas algorithm. At each time step, the Poisson equation, Equation (4), was treated by using the Point Successive Under-Relaxation method (PSUR) with an optimum under-relaxation coefficient equal to 0.8 for the uniform grid $(101 \times 101)$ adopted in the present study. Convergence of iteration for stream function solution is obtained at each time step. The following criterion is employed to check for steady-state solution. Convergence of solutions is assumed when the relative error for each variable between consecutive iterations is recorded below the convergence criterion $\varepsilon$ such that $\sum\left|\left(\phi_{i, j}^{n+1}-\phi_{i, j}^{n}\right) / \phi_{i, j}^{n+1}\right|<10^{-5}$ where $\phi$ stands for $\psi, \theta, \omega, n$ refers to time and $i$ and $j$ refer to space coordinates. The time step used in the computations is 2.5.10-5. Grid independency solutions are assured by comparing different grid meshes for the fixed Grashof and Reynolds numbers used in this work ( $G r=104$ and $R e=30$ ) (Table 1). The vorticity computational formula of Woods [33] for approximating the wall vorticity was used:

$$
\omega_{P}=\frac{1}{2} \omega_{P+1}-\frac{3}{\Delta \eta^{2}}\left(\psi_{P+1}-\psi_{P}\right),
$$

where $\psi_{P}$ and $\psi_{P+1}$ are stream function values at the points adjacent to the boundary wall; $\mathrm{n}$ the normal abscise on the boundary wall. Numerical model input parameters are given in Table 2. 
Table 1. Grid independency.

\begin{tabular}{cccccc}
\hline Stage & Grid size & Nus $_{\text {PV1mean }}$ & Change (\%) & $\theta_{P \backslash \max }$ & Change (\%) \\
\hline & $61 \times 101$ & 4.431247 & - & 0.235168 & - \\
Fixed M = 101 & $81 \times 101$ & 4.435421 & 2.770021 & 0.225283 & 0.049304 \\
$\quad$ N varied & $101 \times 101$ & 4.424182 & 0.254946 & 0.219500 & 2.634709 \\
& $121 \times 101$ & 4.677345 & 5.412523 & 0.213627 & 2.675483 \\
& $101 \times 61$ & 4.997354 & - & 0.219694 & - \\
Fixed N = 101 & $101 \times 81$ & 4.926079 & 1.446903 & 0.218492 & 0.005502 \\
M varied & $101 \times 101$ & 4.918084 & 1.113654 & 0.216003 & 1.152345 \\
& $101 \times 121$ & 4.849204 & 1.420444 & 0.217426 & 3.011568 \\
\hline
\end{tabular}

Table 2. Numerical model input parameters.

\begin{tabular}{cc}
\hline Parameters & Value \\
\hline Transmittance of the glaze, $\tau_{g l}$ & $0.95(-)$ \\
Absorptivityof PV cells surface, $\alpha_{P V}$ & $0.89(-)$ \\
Transmittance of PV cells surface, $\tau_{P V}$ & $0.09(-)$ \\
Absorptivity of back plate, $\alpha_{P}$ & $0.05(-)$ \\
$\quad$ Width of the channel, $d$ & $0.05(\mathrm{~m})$ \\
Length of the building, $L$ & $1.0(\mathrm{~m})$ \\
Length of the channel, $H_{2}$ & $0.50(\mathrm{~m})$ \\
Fluid flow duct width, $d$ & $0.05(\mathrm{~m})$ \\
Heigth of the building, $H_{1}$ & $0.5(\mathrm{~m})$ \\
\hline
\end{tabular}

\section{Results and Discussion}

\subsection{Validation}

In order to test the computer code developed for this study, the problem of a ventilated rectangular enclosure with its left wall submitted to a constant heat flux, while the remaining walls are considered adiabatic was studied. Very good agreement is obtained between the test problem solution and the ventilated rectangular enclosure solutions according to the work of A. Raji et al.

Where the horizontal cold jet enters into the enclosure from the top of its heated wall and leaves from the top of the other vertical one with no slip boundary conditions applied to all the walls. The Reynolds number, Re was set at 200, for Raleigh number Ra set at 106. The numerical analysis predicted values of streamlines and isotherms together with ventilated rectangular enclosure results are shown in Figure 2.

\subsection{Flow Visualization}

Figures 3(a)-(c) indicates the shape of streamlines and isotherms at a fixed Rayleigh number $(R a=104)$ for different Reynolds numbers. One can observe in Figure 3(a) that for $R e=50$, the isotherms are very concentrated in the gaps of the chimneys. This tendency proves that the integration of the associated solar 
hybrid photovoltaic chimneys into the building promotes the passive cooling for the relative size of the habitat. The cold zone observed in the room varies increasingly when the Reynolds number increases, Figure 3(a), Figure 3(b). There are two types air flows in the integrated solar chimneys.

One can observe the manifestation of the back flow or reverse flow phenomenon in the chimney type II, whereas the steady flow is more established in the solar hybrid photovoltaic-thermal Trombe wall chimney. The open lines are very concentrated in the gap of the Trombe wall chimney integrated in the south façade of the building. The presence of the open lines in the chimney type I, indicates really the forced convection in this zone of the cavity. There are permanent closed cells in the room, where their sizes increase with the Reynolds number. The simultaneous existence of closed cells of natural convection and the open lines indicates that the manifestation of mixed convection phenomenon in the vented bioclimatic building. Then mixed convection is indicated to evacuate the heat excess in the associated chimneys integrated into a building. Then, the air flow behind the solar photovoltaic cells plates induced by buoyancy forces has reduced the module's temperature. The same results are obtained by Brinkworth et al. [13].

The variation of the absolute temperature along the PV cells plates of the chimneys is observed in Figure 4(a), Figure 4(b). In this figure, one can observe that the temperature increases with the Reynolds number in the chimney type II, while it decreases in the Trombe wall chimney. One can conclude that the associated chimneys are playing simultaneously the antagonist role for the habitat passive cooling. The opposite phenomenon is observed the variation of heat transfer exchange along the heated solar PV plates along the chimneys, Figure 5(a), Figure 5(b).

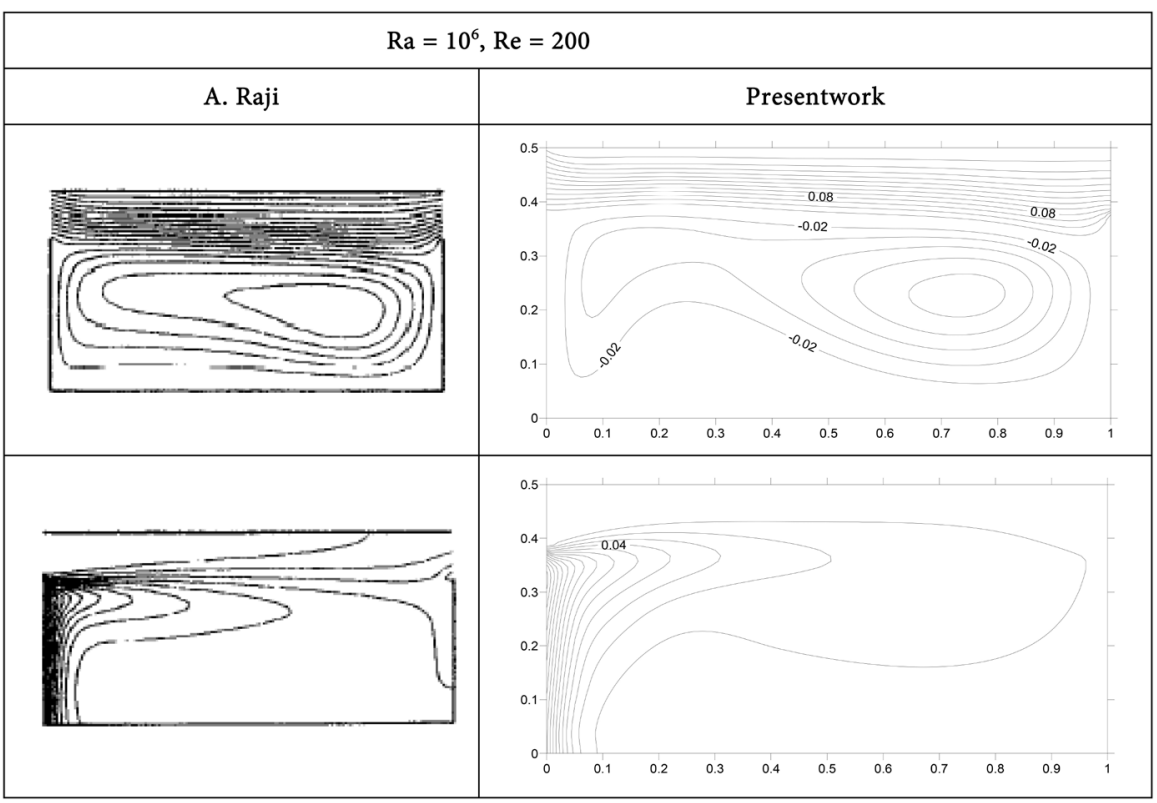

Figure 2. Comparison of streamlines and isotherms. 

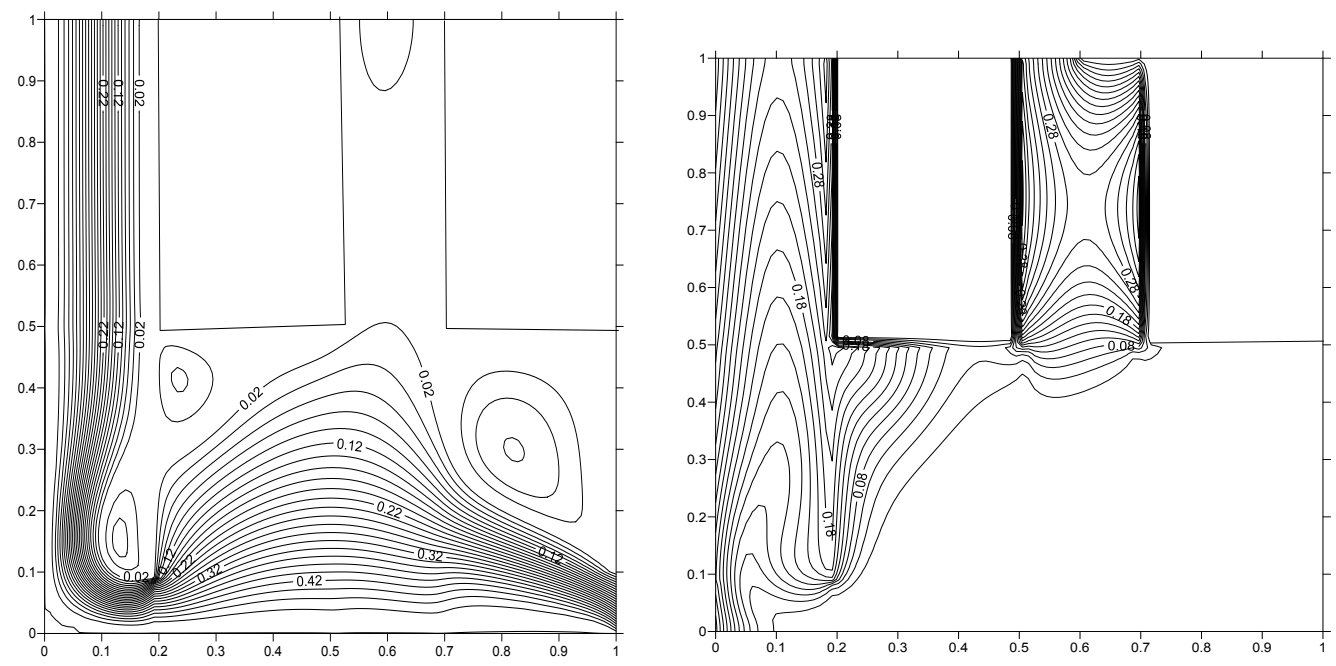

(a)
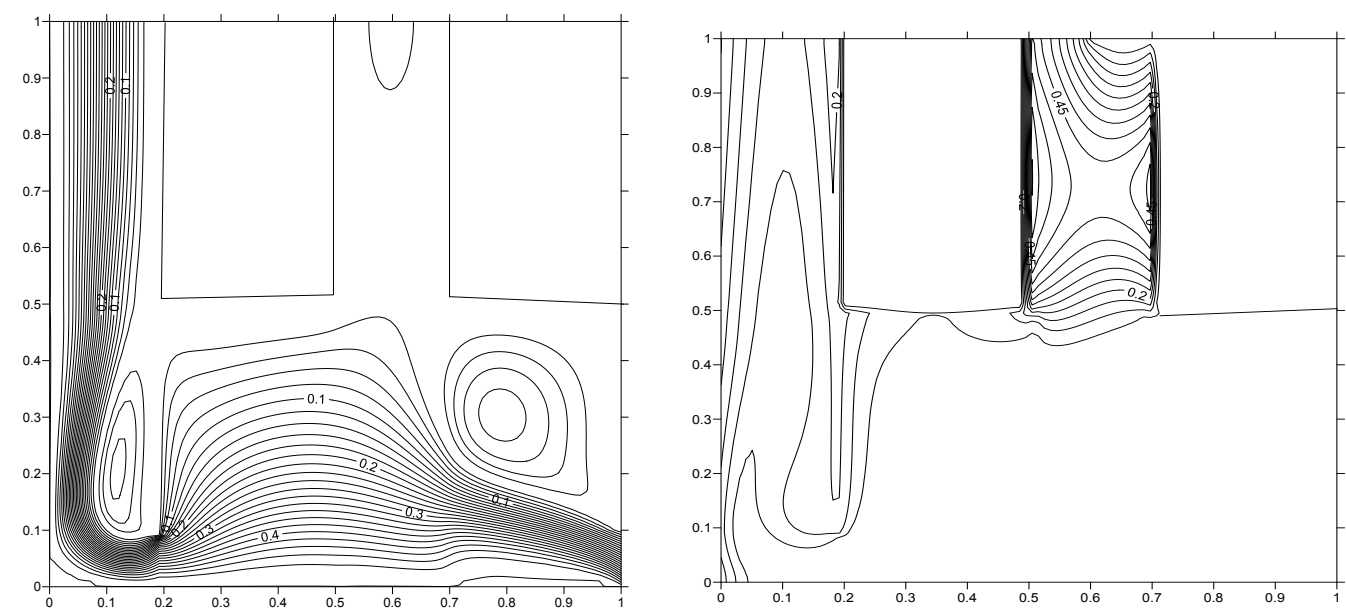

(b)
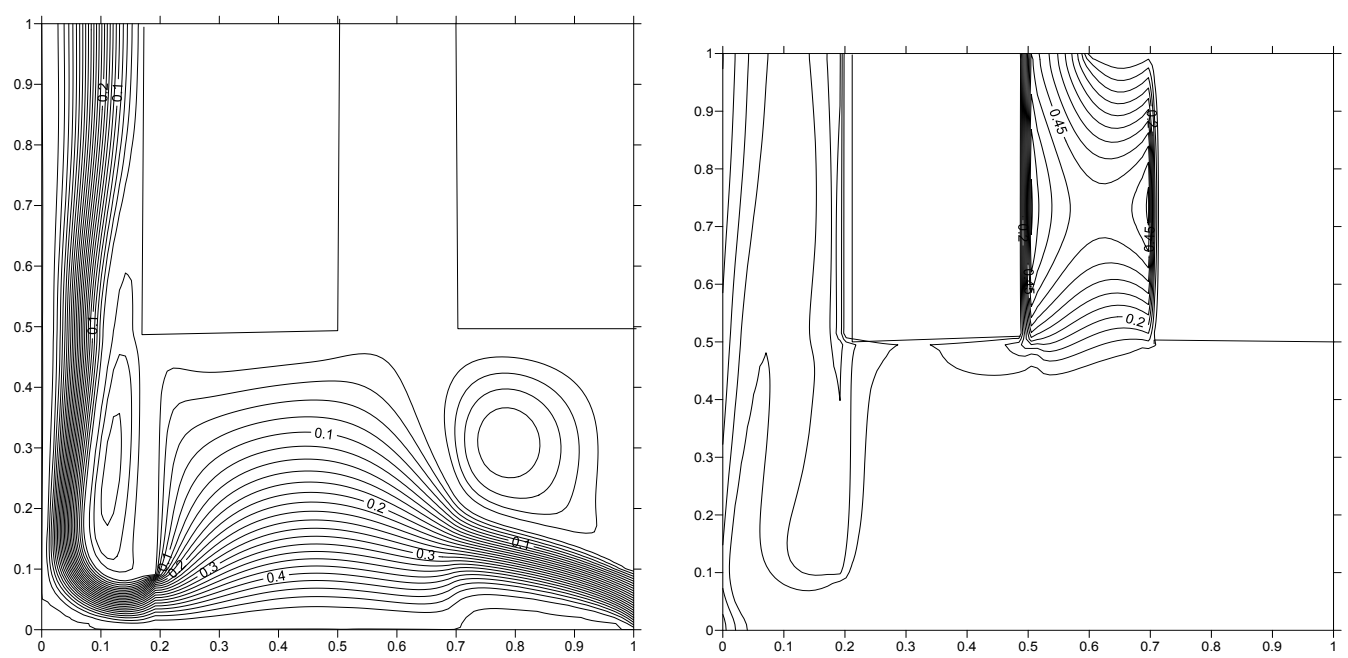

(c)

Figure 3. Streamlines and isotherms for fixed Rayleigh number for various Reynolds numbers $R a=104$, (a) $R e=50$, (b) $R e=100$; (c) $\operatorname{Re}=150$. 

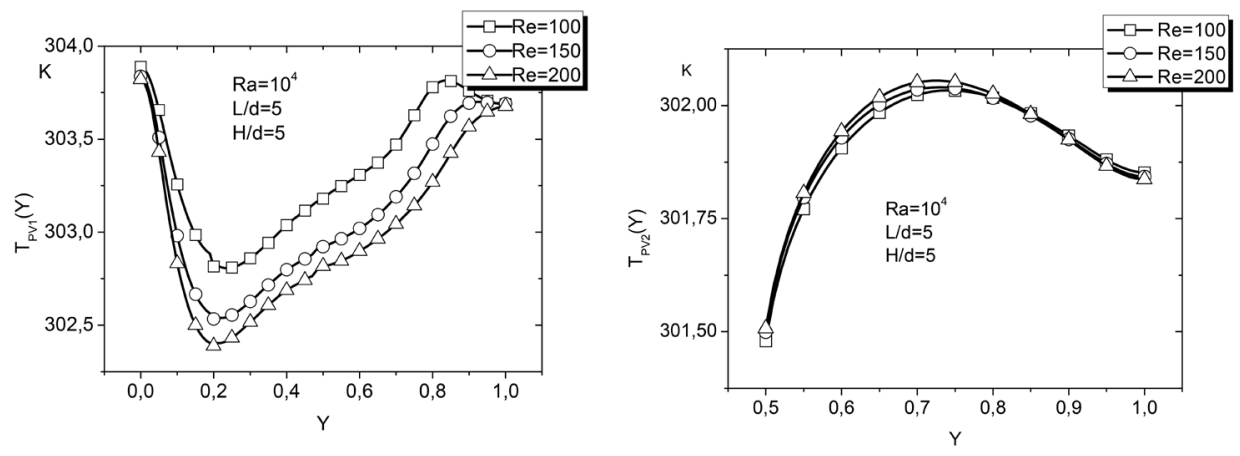

Figure 4. Variation of the temperature along the PV cells plate versus Reynolds number.
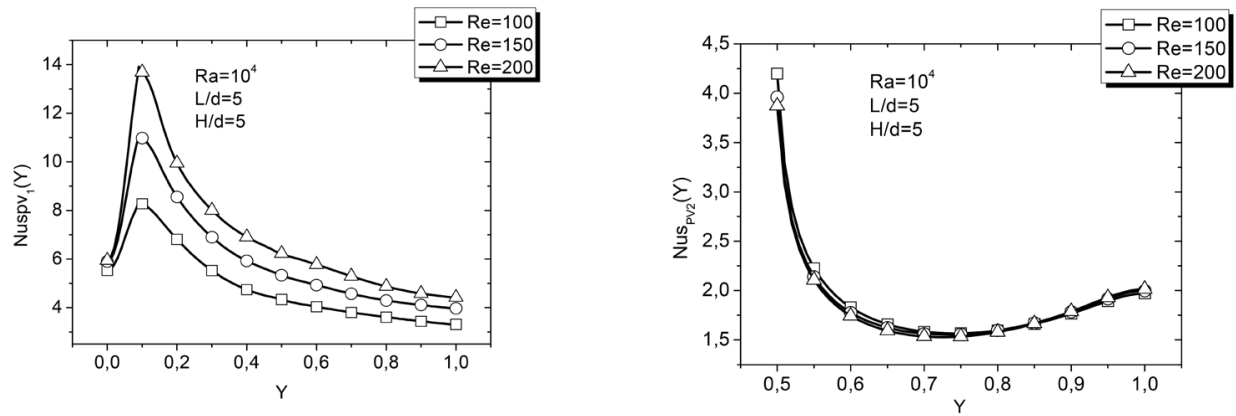

Figure 5. Variation of Nusselt number along the PV cells plate versus Reynolds number.

\subsection{Chimney Type II Position Effect}

The position of the chimney is a key controlling parameter for air cooling in the building. Then, Figures 6(a)-(c) gives more illustration of the movement of the coolant fluid in the bioclimatic building. Hence, in Figure 6(a), where the chimney type II is located near the Trombe wall channel, one can observe the simultaneous existence of the closed cells and the open lines in the bioclimatic building design. This position of the hybrid photovoltaic-thermal chimney promotes the best heat exchange in the associated chimneys. The thermal plume is clearly observed in the gaps of the chimneys, due to a large cold zone obtained for maintaining the thermal comfort in the building. This obvious situation is observed via the isothermal shape obtained in the chimneys. The isotherms bifurcations indicate the mixed convection phenomenon in the vented bioclimatic building, due to the existence of open lines and the closed cells in the room. Then, one can observe in Figure 6(b), Figure 6(c), that the size of the closed cells decrease when the location of the chimney type II, is far from the Trombe wall chimney which is constantly located at the south façade of the building. This situation prevents the existence of Rayleigh Bernard natural convection closed cells in the cavity. Hence the forced flow is dominant than the natural convection, due to a large number of open lines in the last architect cavity design. Then, Figure 6(c) the extremely location of chimney type II, is a strategy to keep the ambient temperature in the building for thermal comfort. In this way, one can reduce the air conditioned energy load. 

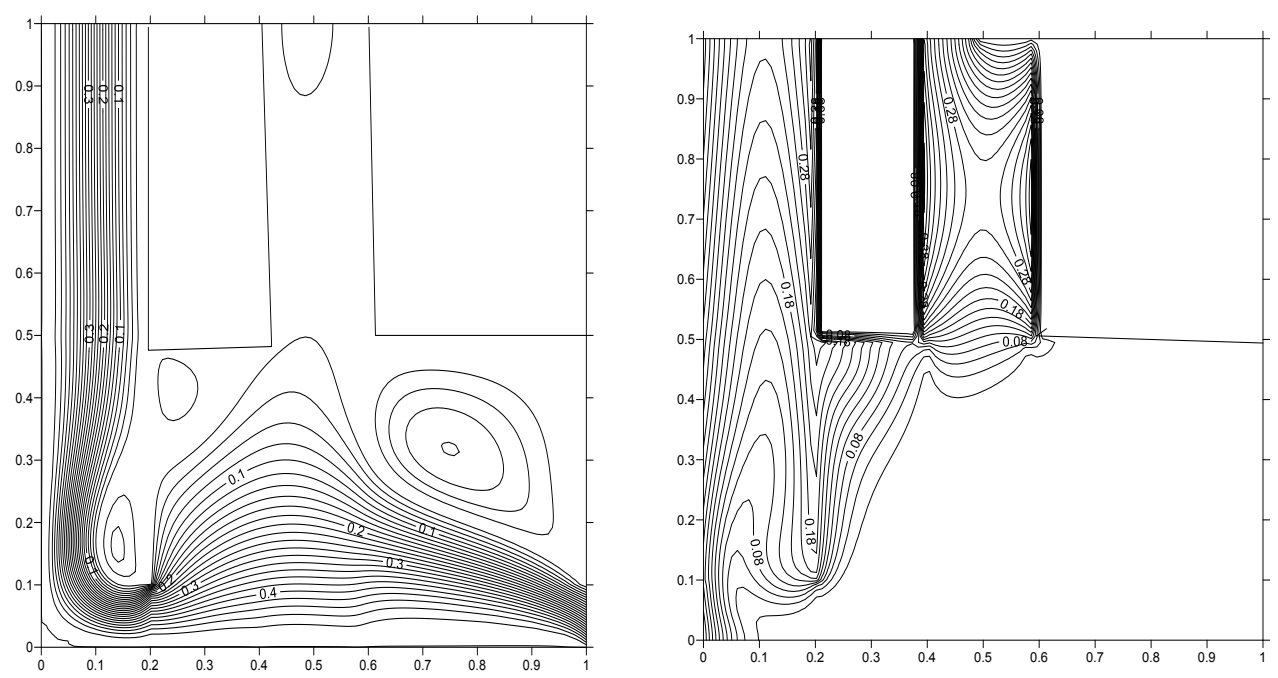

(a)
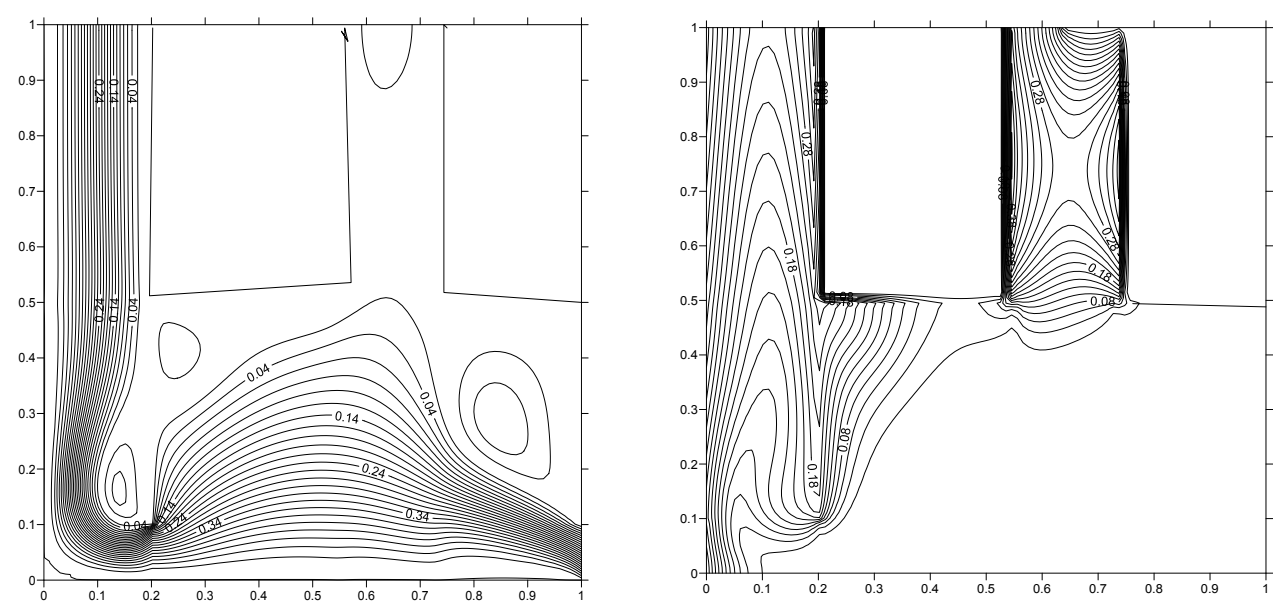

(b)
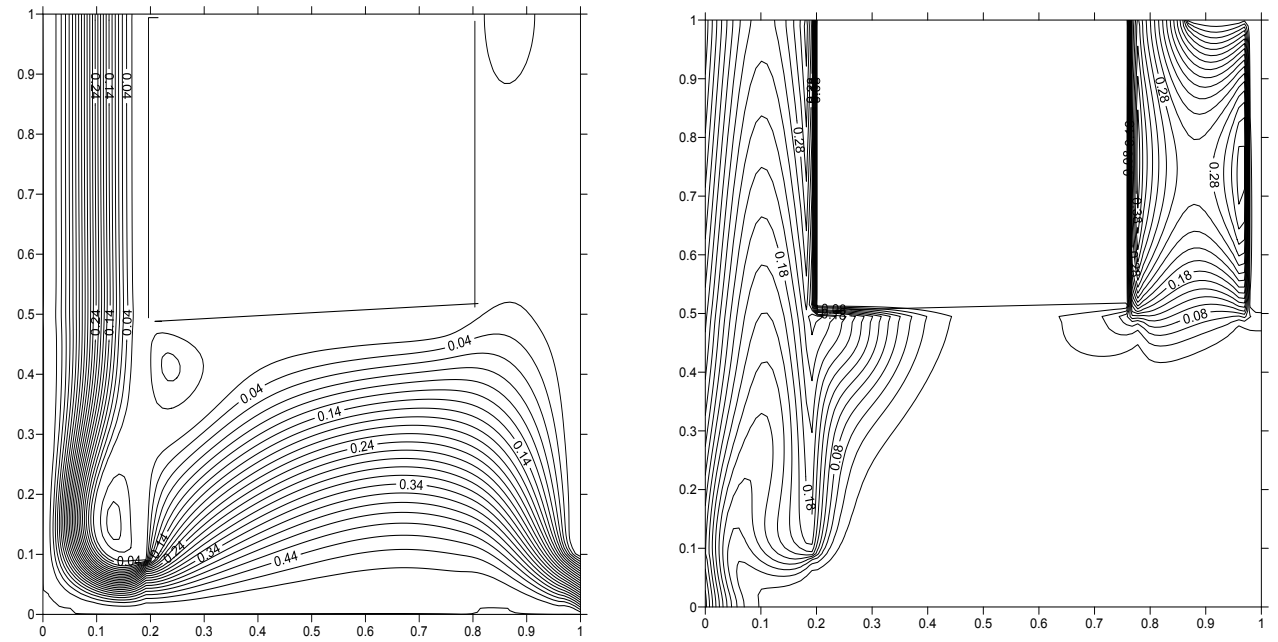

(c)

Figure 6. Streamlines and isotherms for fixed Reynolds and Rayleigh numbers for various positions of the chimney type II, $R e=50, R a=104$, (a) LA $=2.5$; (b) $\mathrm{LA}=4$; (c) LA $=6$. 
For any location case of the chimney type II, in Figure 7(a), the local Nusselt number increases to attain the maximal value before decreasing along the remain PV cells plate in the Trombe wall chimney. But the opposite variation of local Nusselt number is observed along the PV cells plate in the hybrid photovoltaic - thermal chimney. Hence, in this situation, the Nusselt number decreases to attain the minimal value before increasing along the remain PV cells plate, Figure 7(b). These variations of the local Nusselt number prove sufficiently that the association of the cooling cavity and the Trombe wall chimney integrated into the building, give more possibility for passive cooling in the large habitat. This passive cooling technique can reduce the building energy consumption.

\subsection{Effect of the Height of the Chimneys}

In Figure 8(a), Figure 8(b), the outlet velocity increases to attain the maximum value before it decreases along the solid walls which limited the separation of the chimneys. No sleep conditions are observed along the limitation solid walls along the chimneys. In particularly, one can observe that, the outlet velocity is a decreasing function of the height of the chimney at the outlet opening of the Trombe wall chimney, (chimney type I), Figure 8(a); while it becomes an increasing function at the outlet opening of the chimney type II, Figure $8(\mathrm{~b})$. The existence of the two peaks in the variation of the outlet velocity in chimney type II, is a proof of the back flow phenomenon observed in the shape of the streamlines. Other where, the stabilized flow is observed in the chimney type I, due to the unique peak of the outlet velocity variation in this design chimney. In Figure 9(a), Figure 9(b), the outlet opening temperature curves have the maximum value near the chimneys limitation plates.

The minimum values are observed at the middle of the chimneys, because, the heat exchange is more important at the vicinity of the heated plates. One can observe that the outlet temperature is an increasing function of the height of the chimney, because, longer is the chimney height, higher is the flow duration along the chimney. Due to the coolant fluid to have the best heat exchange along the bioclimatic building, this practice has an important interest to keep constant the temperature of habitation space in the room at the fresh air ambient temperature to overcome to the thermal comfort.

\subsection{Effect of the Width of the Chimneys}

The width of chimney is an important controlling parameter of the heat exchange in the depth of the chimney. Hence, Figure 10(a), Figure 10(b) indicates that the intensity of the heat exchange is an increasing function of the chimney width.

The local Nusselt number is an inverse relation of the dimensionless temperature. Then, smaller is the width, higher is Nusselt number along the heated PV cells plates. The peak observed in the variation of Nusselt number along the PV cells plate in the Trombe wall chimney, gives more explication that the heat exchange is weak in this entry zone of the PV cells plate perfectly vented by the 
fresh air, and then it decreases along the remain PV plate as the same variation observed along the heated PV plate in the chimney type II.
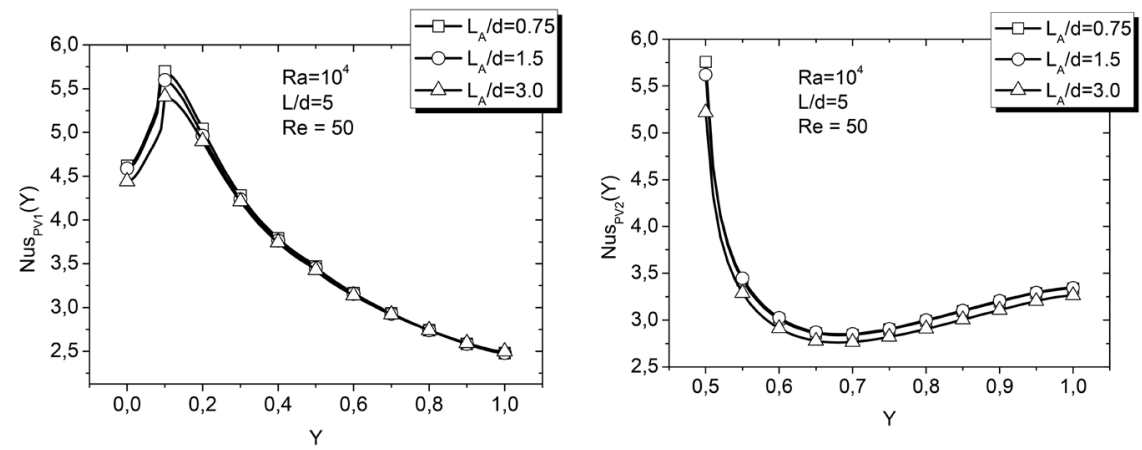

Figure 7. Variation of Nusselt number along the PV cells plate versus chimney type II position.
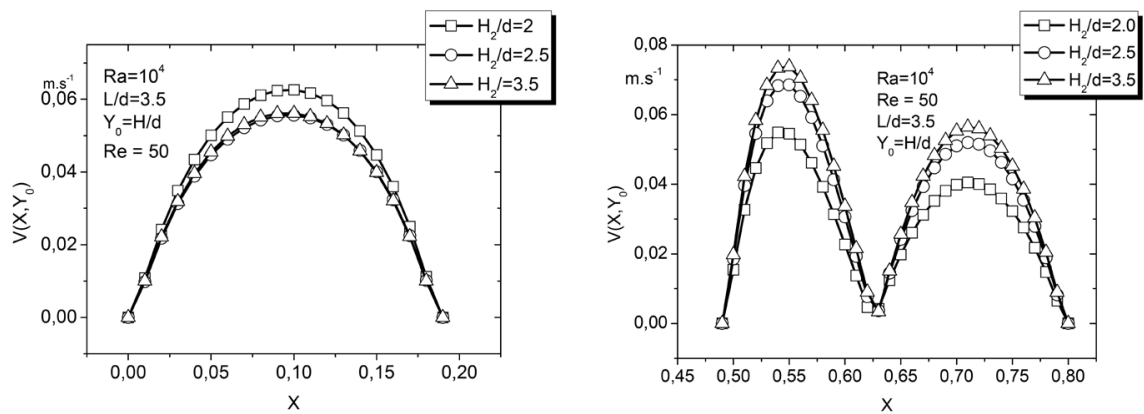

Figure 8. Variation of the outlet velocity versus chimney width.
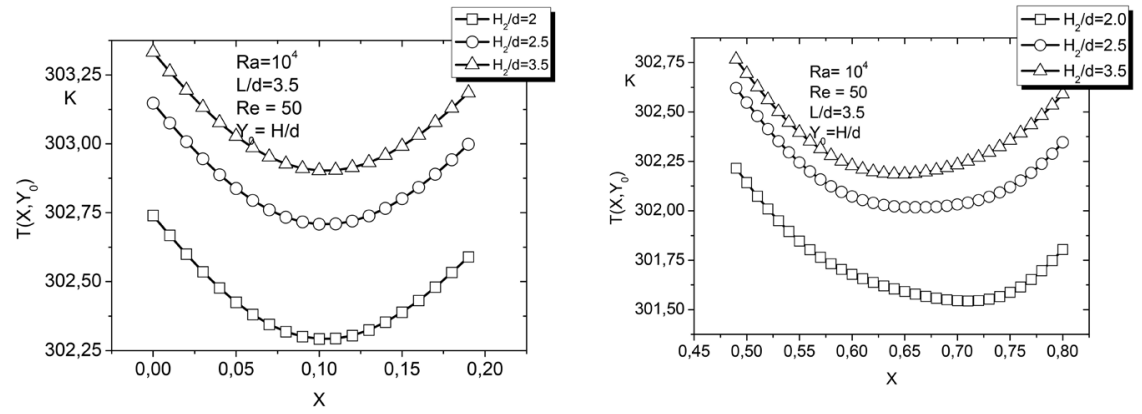

Figure 9. Variation of outlet temperature versus the chimney height.
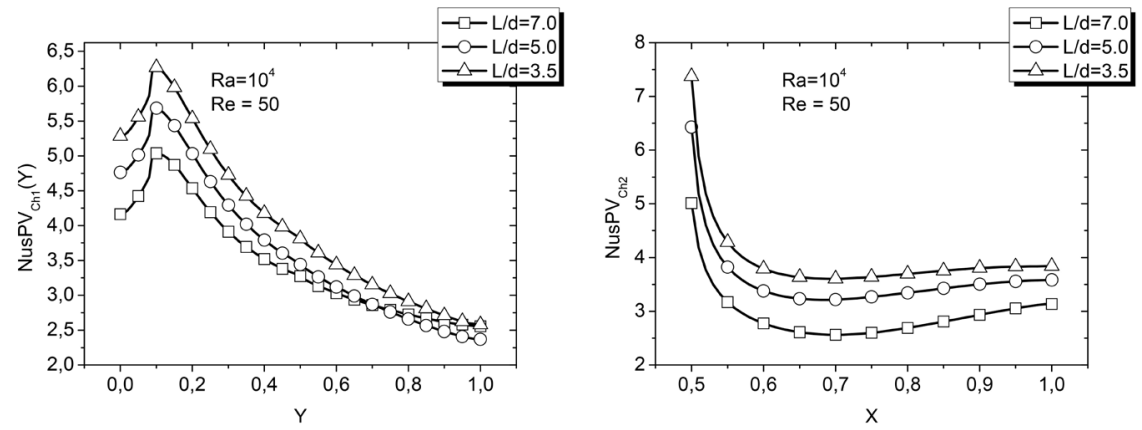

Figure10. Variation of Nusselt number along the PV cells plate versus chimney width. 
The chimney width size has an important effect on the variation of the solar PV cells electrical output. Then the curves of variation of the electrical efficiency of the solar PV cells along the chimneys in Figure 11(a), Figure 11(b) indicated that there is a strongly relation between the chimney size and the electrical efficiency of the solar PV module.

In Figure 11(a), the PV cells electrical efficiency decreases for the weak values of the size of the chimney while it increases for the high value of the width size. This result indicates that authors to attain the optimum value of the Trombe wall chimney width to obtain the maximum PV cells electrical efficiency. Other where, the maximum value of PV cells electrical efficiency is attained for the weak value of the chimney width value, Figure 11(b)

One can conclude that the associated hybrid photovoltaic chimneys integrated into the building are doing the complementary role in the passive cooling effect for the space habitation in the room. Then, in Figure 12, the outlet temperature in the Trombe wall chimney is a decreasing function of the width of the chimney. Consequence, larger is the chimney width, higher is the PV cells electrical efficiency, thus the PV cells plate are perfectly vented and the excess of the heat is permanent evacuated.
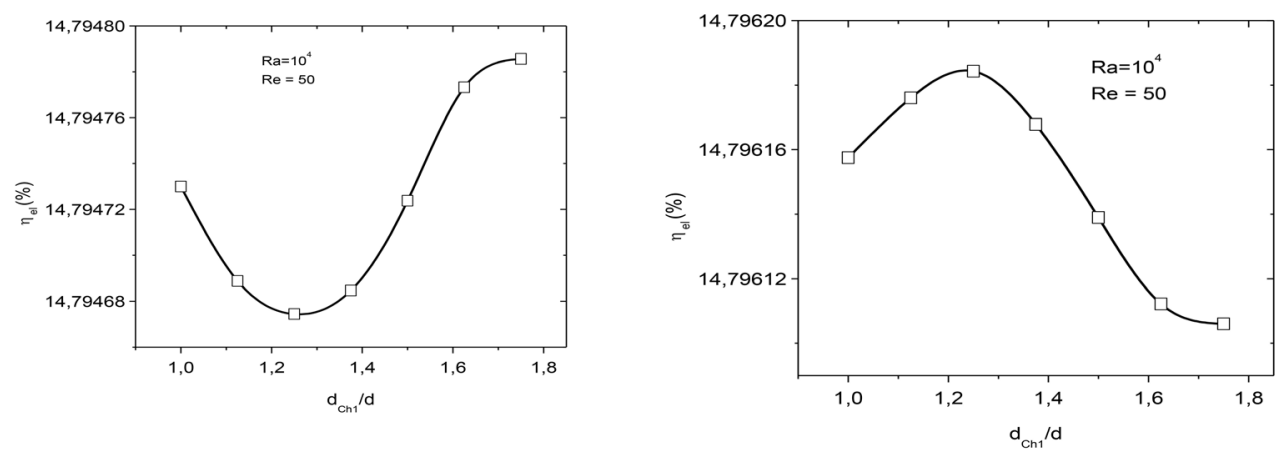

Figure 11. Variation of PV cells electrical efficiency versus chimney width.

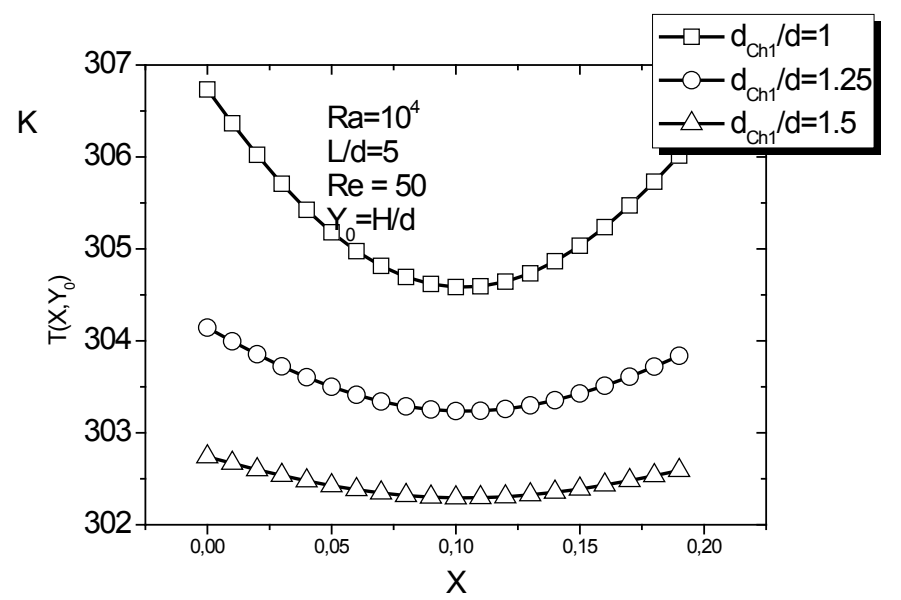

Figure 12. Variation of temperature at outlet opening of the chimney type I versus chimney width. 


\section{Conclusions}

A numerical investigation of laminar mixed-convective cooling in the associated hybrid photovoltaic-thermal chimney integrated into the building has been conducted to identify the optimum placement of the cooling cavity or chimney type II for the best cooling effectiveness. The study encompasses for ranging Rayleigh number $103 \leq R a \leq 105$, Reynolds numbers from $30 \leq R e \leq 200$ representing dominating forced convection trough mixed convection to dominating natural convection. The local, Nusselt number along the heated walls have been used to evaluate the cooling effectiveness in the integrated chimneys. The results indicated that there is a strongly relation between the chimney size and the electrical efficiency of the solar PV module.

The associated integrated chimneys into the building are permanent doing the complementary role for passive cooling in the bioclimatic building, and the load for energy consumption of the conditioned air and the electricity would be considerably reduced, hence the energy autonomy of the bioclimatic buildings.

The practice of the association of the Trombe wall chimney and the hybrid photovoltaic-thermal chimney has an important interest to keep constant the temperature of habitation space in the room at the fresh air ambient temperature to overcome to the thermal comfort.

\section{Conflicts of Interest}

The authors declare no conflicts of interest regarding the publication of this paper.

\section{References}

[1] Ürge-Vorsatz, D., Cabeza, L.F., Serrano, S., Barreneche, C. and Petrichenko, K. (2015) Heating and Cooling Energy Trends and Drivers in Buildings. Renewable and Sustainable Energy Reviews, 41, 85-98. https://doi.org/10.1016/j.rser.2014.08.039

[2] Abbassi, F., Dimassi, N. and Dehmani, L. (2014) Energetic Study of a Trombe Wall System under Different Tunisian Building Configurations. Energy and Buildings, 80, 302-308. https://doi.org/10.1016/j.enbuild.2014.05.036

[3] Byrne, P., Miriel, J. and Lénat, Y. (2012) Modelling and Simulation of a Heat Pump for Simultaneous Heating and Cooling. Building Simulation, 5, 219-232. https://doi.org/10.1007/s12273-012-0089-0

[4] Chan, H.-Y., Riffat, S.B. and Zhu, J. (2010) Review of Passive Solar Heating and Cooling Technologies. Renewable and Sustainable Energy Reviews, 14, 781-789. https://doi.org/10.1016/j.rser.2009.10.030

[5] Hussain, F., Othman, M.Y.H., Sopian, K., Yatim, B., Ruslan, H. and Othman, H. (2013) Design Development and Performance Evaluation of Photovoltaic/Thermal (PV/T) Air Base Solar Collector. Renewable and Sustainable Energy Reviews, 25, 431-441. https://doi.org/10.1016/j.rser.2013.04.014

[6] Brinkworth, B.J., Cross, B.M., Marshall, R.H. and Yang, H.X. (1997) Thermal Regulation of Photovoltaic Cladding. Solar Energy, 61, 169-178. https://doi.org/10.1016/S0038-092X(97)00044-3 
[7] Fiaschi, D. and Bertolli, A. (2012) Design and Exergy Analysis of Solar Roofs: A Viable Solution with Esthetic Appeal to Collect Solar Heat. Renewable Energy, 46, 60-71. https://doi.org/10.1016/j.renene.2012.03.013

[8] Briga-Sá, A., Martins, A., Boaventura-Cunha, J., Lanzinha, J.C. and Paiva, A. (2014) Energy Performance of Trombe Walls: Adaptation of ISO 13790:2008(E) to the Portuguese Reality. Energy and Buildings, 74, 111-119. https://doi.org/10.1016/j.enbuild.2014.01.040

[9] Hami, K., Draoui, B. and Hami, O. (2012) The Thermal Performances of a Solar Wall. Energy, 39, 11-16. https://doi.org/10.1016/j.energy.2011.10.017

[10] Fang, X. and Yang, T. (2008) Regression Methodology for Sensitivity Analysis of Solar Heating Walls. Applied Thermal Engineering, 28, 2289-2294.

[11] Hordeski, M.F. (2004) Dictionary of Energy Efficiency Technologies. Fairmont Press, West Virginia.

[12] Liu, Y.W. and Feng, W. (2012) Integrating Passive Cooling and Solar Techniques into the Existing Building in South China. Advanced Materials Research, 368-373, 3717-3720. https://doi.org/10.4028/www.scientific.net/AMR.368-373.3717

[13] Zhai, X.Q., Song, Z.P. and Wang, R.Z. (2011) A Review for the Applications of Solar Chimneys in Buildings. Renewable and Sustainable Energy Reviews, 15, 3757-3767. https://doi.org/10.1016/j.rser.2011.07.013

[14] Givoni, B. and La Roche, P. (2001) Radiant Cooling Systems for Developing Countries. Accepted for ISES 2001, Adelaide, 1-6.

[15] Barozzi, G., Imbabi, M.S.E., Nobile, E. and Sousa, A.CC.M. (1992) Physical and Numerical Modeling of a Solar Chimney-Based Ventilation System for Buildings. Building and Environment, 27, 433-445. https://doi.org/10.1016/0360-1323(92)90042-N

[16] Hirunlabh, J., Wachirapuwadon, S., Pratinthong, N. and Khedari, J. (2001) New Configurations of a Roof Solar Collector Maximizing Natural Ventilation. Building and Environment, 36, 383-391. https://doi.org/10.1016/S0360-1323(00)00016-0

[17] Bansal, N.K., Mathur, R. and Bhandari, M. (1994) A Study of Solar Chimney Assisted Wind Tower System for Natural Ventilation in Buildings. Building and Environment, 29, 495-500. https://doi.org/10.1016/0360-1323(94)90008-6

[18] Wei, D., Qirong, Y. and Jincui, Z. (2011) A Study of the Ventilation Performance of a Series of Connected Solar Chimneys Integrated with Building. Renewable Energy, 36, 265-271. https://doi.org/10.1016/j.renene.2010.06.030

[19] Rabani, M., Kalantar, V., Dehghan, A.A. and Faghih, A.K. (2015) Empirical Investigation of the Cooling Performance of a New Designed Trombe Wall in Combination with Solar Chimney and Water Spraying System. Energy and Buildings, 102, 45-57. https://doi.org/10.1016/j.enbuild.2015.05.010

[20] Verma, R., Bansal, N. and Garg, H. (1986) The Comparative Performance of Different Approaches to Passive Cooling. Building and Environment, 21, 65-69. https://doi.org/10.1016/0360-1323(86)90012-0

[21] Mathews, E.H., Kleingeld, M. and Grobler, L.J. (1994) Integrated Simulation of Buildings and Evaporative Cooling Systems. Building and Environment, 29, 197-206. https://doi.org/10.1016/0360-1323(94)90070-1

[22] Dai, Y., Sumathy, K., Wang, R. and Li, Y. (2003) Enhancement of Natural Ventilation in a Solar House with a Solar Chimney and a Solid Adsorption Cooling Cavity. Solar Energy, 74, 65-75. https://doi.org/10.1016/S0038-092X(03)00106-3

[23] Nougbléga, Y., N’wuitcha, K., Kpode, K., Atchonouglo, K. and Banna, M. (2019) 
Numerical Study of Mixed Convection in the Photovoltaic Tromb Wall Window for Passive Cooling in Bioclimatic Buildings. International Journal of Advanced Research, 6, 911-926. https://doi.org/10.21474/IJAR01/7594

[24] Nougbléga, Y., Kpode, K., N’Wuitcha, K. and Banna, M. (2019) Thermal Efficiency of a Hybrid Photovoltaic-thermal Chimney. Integrated Into a Building. American Journal of Modern Physics, 8, 50-65. https://doi.org/10.11648/j.ajmp.20190804.11

[25] Khedari, J., Rachapradit, N. and Hirunlabh, J. (2003) Field Study of Performance of Solar Chimney with Air-Conditioned Building. Energy, 28, 1099-1114. https://doi.org/10.1016/S0360-5442(03)00092-6

[26] Imran, A.A., Jalil, J.M. and Ahmed, S.T. (2015) Induced Flow for Ventilation and Cooling by a Solar Chimney. Renewable Energy, 78, 236-244.

https://doi.org/10.1016/j.renene.2015.01.019

[27] Punyasompun, S., Hirunlabh, J., Khedari, J. and Zeghmati, B. (2009) Investigation on the Application of Solar Chimney for Multi-Storey Buildings. Renewable Energy, 34, 2545-2561. https://doi.org/10.1016/j.renene.2009.03.032

[28] Haghighi, A. and Maerefat, M. (2014) Solar Ventilation and Heating of Buildings in Sunny Winter Days Using Solar Chimney. Sustainable Cities and Society, 10, 72-79. https://doi.org/10.1016/j.scs.2013.05.003

[29] Zhai, X., Dai, Y. and Wang, R. (2005) Comparison of Heating and Natural Ventilation in a Solar House Induced by Two Roof Solar Collectors. Applied Thermal Engineering, 25, 741-757. https://doi.org/10.1016/j.applthermaleng.2004.08.001

[30] Chungloo, S. and Limmeechokchai, B. (2007) Application of Passive Cooling Systems in the Hot and Humid Climate: The Case Study of Solar Chimney and Wetted Roof in Thailand. Building and Environment, 42, 3341-3351.

https://doi.org/10.1016/j.buildenv.2006.08.030

[31] Chungloo, S. and Limmeechokchai, B. (2009) Utilization of Cool Ceiling with Roof Solar Chimney in Thailand: The Experimental and Numerical Analysis. Renewable Energy, 34, 623-633. https://doi.org/10.1016/j.renene.2008.05.026

[32] Rabani, R., Faghih, A.K., Rabani, M. and Rabani, M. (2014) Numerical Simulation of an Innovated Building Cooling System with Combination of Solar Chimney and Water Spraying System. Heat and Mass Transfer, 50, 1609-1625. https://doi.org/10.1007/s00231-014-1366-5

[33] Woods, L.C. (1954) A Note of Numerical Solution of Fourth Differential Equations. The Aeronautical Quarterly, 5, 176-184. https://doi.org/10.1017/S0001925900001177 


\section{Nomenclature}

$C P$ : $\quad$ Specific heat $\left(\mathrm{J} \cdot \mathrm{kg}^{-1} \cdot \mathrm{K}^{-1}\right)$

$d \quad: \quad$ Chimney width $(\mathrm{m})$

$g$ : Gravitational acceleration $\left(\mathrm{m} \cdot \mathrm{s}^{-2}\right)$

$d_{1}: \quad$ Chimney type I width (m)

$d_{2}: \quad$ Chimney type II width (m)

$e^{*}: \quad$ Aspect ratio dimensionless of the inlet Opening $e^{*}=\frac{e}{d}$

$e_{w}^{*}: \quad$ Aspect ratio dimensionless of the Trombe wall inlet opening $e_{w}^{*}=\frac{e_{w}}{d}$

$L^{*} \quad$ : Aspect ratio dimensionless length of the global system $L^{*}=L / d$

$H^{*}$ : Aspect ratio dimensionless height of the global system $H^{*}=H / d$

$L_{A}^{*}: \quad$ Aspect ratio dimensionless length of the room before the chimney type II $L_{A}^{*}=\frac{L_{A}}{d}$

$d_{1}^{*}: \quad$ Aspect ratio chimney type I width $d_{1}^{*}=\frac{d_{1}}{d}$

$d_{2}^{*}: \quad$ Aspect ratio chimney type II width $d_{2}^{*}=\frac{d_{2}}{d}$

$H_{1}^{*}: \quad$ Aspect ratio dimensionless height of the room $H_{1}^{*}=\frac{H_{1}}{d}$

$H$ : Total height of the enclosure (m)

$L \quad: \quad$ Total length of the enclosure (m)

$n$ : Coordinate in normal direction

$t$ : Time (s)

$T: \quad$ Temperature (K)

$T_{a}: \quad$ Ambient air temperature (K)

$u, v: \quad$ Velocity component in $\mathrm{x}$ and $\mathrm{y}$ directions $\left(\mathrm{m} \cdot \mathrm{s}^{-1}\right)$

$U, V: \quad$ Dimensionless velocity component in $X$ and $Y$ directions; $U=u / u_{0}$, $V=v / u_{0}$

$u_{0}: \quad$ Air inlet velocity $\left(\mathrm{m} \cdot \mathrm{s}^{-1}\right)$

$e \quad: \quad$ Air inlet opening width (m)

$x, y: \quad$ Coordinates defined in Figure $1(\mathrm{~m})$

$X, Y: \quad$ Dimensionless spatial coordinates; $X=x / d, Y=y / d$

Re : Reynolds number $R e=\left(\rho v_{0} d\right) / \mu$

$\operatorname{Pr}: \quad$ Prandlt number $\operatorname{Pr}=\mu C P / \lambda$

$N u: \quad$ Nusselt number $N u=(\phi d) / \lambda\left(T-T_{a}\right)$

$G r$ : Grashof number $G r=\left(g \beta \phi d^{4}\right) /\left(\lambda V^{2}\right)$

$R i$ : Thermal Richardson number $R i=G r / R e^{2}$

Greek symbols

$\theta:$ Dimensionless temperature $\theta=\lambda\left(T-T_{a}\right) / \phi d$

$\tau:$ Dimensionless time $\tau=u_{0} t / d$

$\beta$ : Thermal expansion coefficient $\left(\mathrm{K}^{-1}\right)$

$\rho: \quad$ Density of the air $\left(\mathrm{kg} \cdot \mathrm{m}^{-3}\right)$ 
$\lambda: \quad$ Thermal diffusivity of the air $\left(\mathrm{W} \cdot \mathrm{m}^{-1} \cdot \mathrm{K}^{-1}\right)$

$\Omega: \quad \operatorname{Vorticity}\left(\mathrm{s}^{-1}\right)$

$\omega:$ Dimensionless voticity $\omega=\Omega d / u_{0}$

$\mu$ : Dynamic viscosity of the air $\left(\mathrm{kg} \cdot \mathrm{m}^{-1} \cdot \mathrm{s}^{-1}\right)$

$\psi:$ : Stream function $\left(\mathrm{m}^{2} \cdot \mathrm{s}^{-1}\right)$

$\Psi:$ Dimensionless stream function $\Psi=\psi /\left(u_{0} d\right)$

$\phi \quad: \quad$ Solar radiation $\left(\mathrm{W} \cdot \mathrm{m}^{-2}\right)$

Subscripts

PV : PV module

Ch1: Chimney type I

Ch2: Chimney type II

f : Fluid (air)

$\mathrm{cv}:$ Convection 